\title{
HASIL BELAJAR KETERAMPILAN PROSES SAINS SISWA BERBASIS PENDEKATAN INKUIRI PADA MATERI TEORI KINETIK GAS
}

\author{
Dea Fitriana ${ }^{1}$, Zulhelmi ${ }^{2}$, Fakhruddin $^{3}{ }^{3}$ dan Nur Islami ${ }^{4}$ \\ ${ }^{1,2,3,4}$ Progam Studi Pendidikan Fisika FKIP Universitas Riau, Pekanbaru, 28293, Indonesia \\ deazahrah@gmail.com
}

Diajukan: 15 January 2021; Diterima: 20 February 2021; Diterbitkan: 30 April 2021

\begin{abstract}
Abstrak: Proses pembelajaran pada materi teori kinetik gas masih cenderung monoton, siswa tidak dilibatkan secara aktif selama proses pembelajaran berlangsung. Hal ini menyebabkan kurangnya pemahaman siswa terhadap konsep yang disampaikan pada materi ini. Guru harus mampu merancang kegiatan pembelajaran yang berorientasi pada proses, sehingga siswa dapat mengembangkan keterampilan ilmiah yang dimiliki. Dalam hal ini proses pembelajaran berbasis pendekatan inkuiri sesuai untuk melatih siswa agar tercipta sikap aktif, berpikir kritis, mampu memecahkan masalah, sehingga tercapai hasil belajar yang baik. Penelitian ini bertujuan untuk mendeskripsikan hasil belajar keterampilan proses siswa melalui penerapan media pembelajaran teori kinetika gas berdasarkan pendekatan inkuiri. Metode yang digunakan dalam penelitian ini adalah desain One Shoot Case Study. Subjek penelitian ini adalah kelas XI MIA 3 SMA Negeri 4 Pekanbaru. Instrumen pengumpulan data adalah tes hasil belajar keterampilan proses pembelajaran. Teknik analisis data yang digunakan adalah analisis deskriptif. Hasil penelitian menunjukkan rata-rata daya serap keterampilan proses siswa berada pada kategori baik sebesar $74,95 \%$. Tingkat keterampilan proses menunjukkan $81,25 \%$ siswa memiliki keterampilan dasar yang baik, sedangkan keterampilan terintegrasi adalah $68,75 \%$. Dapat disimpulkan bahwa penerapan media pembelajaran dalam bentuk perangkat eksperimental berdasarkan pendekatan inkuiri dapat meningkatkan hasil belajar keterampilan proses siswa dalam materi teori kinetik gas.
\end{abstract}

Kata Kunci: Hasil Belajar, Keterampilan Proses, Inkuiri

\begin{abstract}
The learning process in the gas kinetic theory material is still practically monotonous; the students are not actively involved during the learning process. These things lead to students understanding of the concepts conveyed in this material. The teacher must be able to adjust the process-oriented learning activities, and allow students to develop their abilities. In this case, the inquiry-based learning process is appropriate to train students to be active, think critically, be able to solve problems, produce good results. This study aims to determine the learning outcomes of students' process skills through the implementation of gas kinetic theory learning media based on the inquiry approach. The method used in this research is One Shoot Case Study design. The subject of this research was class XI MIA 3 SMA Negeri 4 Pekanbaru. An Instrument of the data collection was test of the learning result of learning process skills. The data analysis technique used was descriptive analysis. The results showed the average absorption capacity of students' process skills was in a good category at 74,95\%. The level of process skills shows $81,25 \%$ of students have good basic skills, while the integrated skills are $68,75 \%$. It can be concluded that the implementation of learning media in the form of experimental devices based on the inquiry approach can improve the learning outcomes of student's process skills in the material of the kinetic theory of gas.
\end{abstract}

Keywords: Learning Outcomes, Process Skill, Inquiry

\section{Pendahuluan}

Pelaksanaan pembelajaran membawa pengaruh bagi seorang guru dalam menguasai kelas dan melakukan evaluasi pembelajaran. Salah satu evaluasi yang dapat dilakukan oleh seorang guru adalah penilaian keterampilan proses. Trianto (2010: 108) menyatakan bahwa keterampilan proses sains siswa dapat dilihat dari keseluruhan keterampilan ilmiah yang dimiliki siswa untuk menemukan konsep ataupun mengembangkan konsep yang telah ada sehingga kemampuan siswa dapat berkembang. Menurut Funk (1985: 140) keterampilan proses sains siswa terdiri dari keterampilan dasar dan keterampilan terintegrasi. Keterampilan dasar meliputi kemampuan mengukur, mengobservasi, mengkomunikasikan, menyimpulkan, mengklasifikasi dan memprediksi. Sedangkan 
keterampilan terintegrasi meliputi mengidentifikasi variabel, membuat tabulasi data, menyajikan data dalam bentuk grafik, menggambarkan hubungan antar-variabel, mengumpulkan dan mengolah data, menganalisa penelitian, menyusun hipotesis, merumuskan masalah, mendefinisikan variabel secara operasional, merancang penelitian dan melaksanakan eksperimen.

Beberapa peneliti mengatakan bahwa terdapat korelasi antara keterampilan proses sains siswa dengan kemampuan penalaran formal (Oloyede, 2012: 2), prestasi belajar (Osman dan Vebrianto, 2013: 202), kreativitas (Ozdemir dan Dikici, 2017: 66), dan sikap ilmiah (Zeidan \& Jayosi, 2015: 17). Keterampilan proses sains merangsang keingintahuan siswa secara mendalam, sehingga pengajaran fisika secara efisien dapat diwujudkan melalui penerapan keterampilan proses secara simultan (Aydin, 2013: 58). Menurut Jeon dan Park ( 2014: 647-655) keterampilan proses merupakan kunci dalam pencapaian akademik siswa. Siswa dengan kinerja tinggi cenderung kompeten dalam menerapkan pemikiran logis dan sistematis untuk situasi yang kompleks, sehingga siswa dapat memecahkan masalah dengan baik. Keterampilan ini dapat ditingkatkan dengan melibatkan siswa dalam kegiatan ilmiah, salah satu upaya yang dapat diterapkan dengan optimalisasi kegiatan laboratorium berorientasi pada proses.

Saat ini, Pembelajaran fisika masih termasuk dalam kategori pelajaran yang sulit. Terutama pada materi teori kinetik gas yang dianggap sebagai materi yang abstrak, karena berisi banyak konsep sehingga siswa lebih aktif dilibatkan dalam berpikir untuk memahami materi ini. Siswa tidak hanya dituntut untuk bisa mengumpulkan pengetahuan berupa fakta dan konsep, tetapi siswa juga dituntut untuk menemukan sendiri konsep dari materi tersebut. Kondisi ini menyebabkan seorang guru harus cerdas dalam memilih pendekatan pembelajaran yang sesuai untuk diterapkan di kelas agar tujuan dari pembelajaran yang ditunjukkan dengan hasil belajar keterampilan proses siswa dapat tercapai dengan baik. Guru harus mampu membuat kegiatan pembelajaran menjadi bervariasi sehingga pembelajaran tidak berlangsung monoton dan siswa mendapatkan kesempatan untuk menghayati penemuan konsep, terampil dalam berpikir, aktif, kreatif dan terampil dalam memperoleh pengetahuan sebagai suatu keterampilan proses yang harus dicapai (Alfiah, 2015: 163).

Konsep pembelajaran teori kinetik gas akan lebih maksimal tercapai jika siswa dapat melakukan pengamatan langsung. Menurut Nugroho (2012: 237) untuk memperoleh data yang akurat siswa perlu berlatih merumuskan masalah, mengajukan hipotesis, merencanakan percobaan mengamati, mengelompokkan, menafsirkan, membuat kesimpulan, dan mampu mengkomunikasikan kepada orang lain secara lisan maupun tulisan. Hal ini dapat mudah terwujud melalui implementasi pendekatan inkuiri dengan memanfaatkan media pembelajaran berupa alat percobaan teori kinetik gas dan LKPD yang dibagikan pada tiap kelompok.

Proses pembelajaran yang sesuai dengan tujuan pembelajaran Kurikulum 2013 dengan berorientasi pada pendekatan ilmiah salah satunya adalah pendekatan inkuiri (Santoso dan Yuanita, 2016: 9) . Setianingsih, et al (2018: 228) menyatakan bahwa proses pembelajaran dengan pendekatan inkuiri memiliki ciri-ciri: a) Siswa tidak secara langsung dapat menemukan jawaban dari suatu permasalahan; b) Siswa menerapkan keterampilan proses sains; c) Siswa memiliki semangat untuk memecahkan suatu permasalahan; d) Siswa mengusulkan cara-cara pengumpulan data dan pengamatan data; f) Hipotesis dirumuskan oleh siswa; g) Siswa melakukan penelitian secara individu/kelompok untuk menggumpulkan data untuk menguji hipotesis; h) Siswa mengolah data sampai menemukan kesimpulan.

Menurut hasil penelitian yang telah dilakukan oleh Susilo, et al (2018: 163) di kelas $X$ MAN 2 Semarang yang berjumlah 8 kelas menunjukkan bahwa pembelajaran dengan menerapkan pendekatan inkuiri terbimbing maupun inkuiri bebas termodifikasi dapat mempengaruhi prestasi belajar siswa. Hal ini ditunjukkan oleh nilai rata-rata yang diperoleh siswa sebesar 69,014. Metode pembelajaran inkuiri lebih menekankan pada keterlibatan siswa dalam proses pembelajaran. Keterlibatan siswa secara aktif dapat meningkatkan kemampuan siswa dalam berpikir tingkat tinggi.

Pranoto, et al (2018: 240) juga menegaskan bahwa proses pembelajaran 
berbasis inkuiri dapat membuat siswa belajar secara aktif di kelas, mampu meningkatkan hasil belajar, dan juga dapat menghubungkan antara teori dan eksperimen. Hal ini ditunjukkan oleh hasil penelitian yang telah dilakukan bahwa nilai sig. $<0,05$. Selain itu, pembelajaran berbasis inkuiri juga mampu melatih siswa untuk berpikir kritis dengan presentase $51,7 \%$.

Hasil serupa juga telah dibuktikan oleh Rahmanto, et al (2015: 117) yang menyatakan bahwa penerapan pembelajaran berbasis pendekatan inkuiri mampu meningkatkan hasil belajar keterampilan proses sains siswa dengan perolehan gain rata-rata sebesar 0,65 (kategori sedang). Aspek keterampilan yang diukur yaitu prediksi, observasi, inferensi serta komunikasi. Hal ini sesuai dengan salah satu kelebihan inkuiri yaitu mampu mengembangkan keterampilan dan proses kognitif siswa.

Berdasarkan uraian masalah yang telah diungkapkan, penelitian ini bertujuan untuk mendeskripsikan hasil belajar keterampilan proses sains siswa pada materi teori kinetik gas melalui media pembelajaran berbasis pendekatan inkuiri. Pendekatan inkuiri diperlukan dalam pengajaran teori kinetik gas ini agar siswa dapat berpikir scientific. Siswa dapat memahami materi ini dengan melakukan kegiatan eksperimen menggunakan media pembelajaran yang dapat memudahkan siswa dalam proses menemukan konsep teori kinetik gas secara ilmiah berdasarkan kreativitas, penalaran, dan sikap ilmiah siswa.

\section{Metode Penelitian}

Jenis penelitian yang digunakan adalah pre experiment dengan rancangan the one-shot case study (Sugiyono, 2012: 74 ).

\begin{tabular}{cc} 
Perlakuan & Postes \\
\hline $\mathrm{X}$ & $\mathrm{O}$ \\
\hline
\end{tabular}

Keterangan :

$\mathrm{X}=$ Perlakuan dengan penerapan media pembelajaran berupa perangkat percobaan teori kinetik gas berbasis pendekatan inkuiri

$\mathrm{O}=$ Skor hasil belajar keterampilan proses

Penelitian ini menggunakan dua variabel, variabel bebas yaitu pendekatan inkuiri yang selanjutnya dianggap sebagai variabel $\mathrm{X}$ dan variabel terikat yaitu hasil belajar keterampilan proses sains siswa yang selanjutnya dianggap sebagai variabel $\mathrm{O}$.

Sugiyono (2013: 91) menyatakan bahwa sampel merupakan bagian dari jumlah dan karakteristik yang dimiliki oleh populasi tersebut. Pengambilan sampel dilakukan dengan teknik random sampling. Teknik random sampling adalah pengambilan sampling secara random atau tanpa pandang bulu. Dalam teknik ini semua individu dalam populasi baik sendiri-sendiri atau bersamasama diberi kesempatan yang sama untuk dipilih menjadi anggota sampel. Adapun cara yang digunakan dalam random sampling adalah dengan cara undian. Setelah dilakukan dengan cara undian, kelas yang terpilih menjadi kelas sampel adalah kelas XI MIA 3 SMA Negeri 4 Pekanbaru.

Adapun instrumen yang digunakan pada penelitian ini berupa perangkat pembelajaran dan perangkat pengumpulan data. Perangkat pemebelajaran yang diterapkan yaitu RPP, Silabus, Lembar Kerja Peserta Didik (LKPD), dan alat percobaan. LKPD merupakan salah satu sarana yang digunakan guru untuk meningkatkan keterlibatan siswa atau aktivitas siswa dalam proses belajar mengajar. Lembar kerja peserta didik berisi tujuan percobaan, alat dan bahan, rumusan masalah, hipotesis, prosedur percobaan, tabel hasil pengamatan, analisis yang dilengkapi dengan soal, dan kesimpulan. LKPD 3.6/XI///01 berisi tentang bunyi hukum Boyle, aplikasi hukum Boyle dalam kehidupan sehari-hari, dan menyelidiki hukum Boyle. LKPD 3.6/XI///02 berisi tentang penjelasan hukum Gay Lussac, aplikasi hukum Gay Lussac dalam kehidupan sehari-hari, dan menyelidiki hukum Gay Lussac. LKPD 3.6/XI///03 berisi tentang penjelasan hukum Charles, aplikasi hukum Charles dalam kehidupan sehari-hari, dan menyelidiki hukum Charles. LKPD 3.6/XI/I/04 berisi tentang penjelasan hukum Boyle-Gay Lussac, aplikasi hukum Boyle-Gay Lussac dalam kehidupan sehari-hari, dan menyelidiki hukum Boyle-Gay Lussac. Alat percobaan yang digunakan bertujuan untuk menemukan konsep hukum Boyle, hukum Gay Lussac, hukum Charles, dan hukum Boyle-Gay Lussac sesuai gambar 1 . 


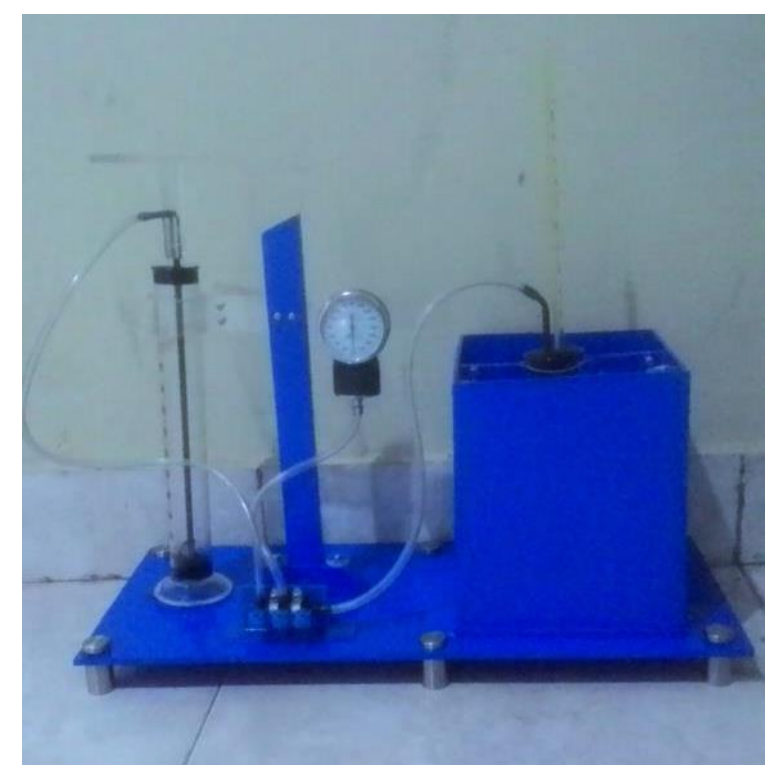

Gambar 1. Alat Percobaan Teori Kinetik Gas

Instrumen pengumpulan data yang digunakan dalam penelitian ini adalah tes essay hasil belajar keterampilan proses. Aspek yang dinilai meliputi keterampilan siswa dalam merumuskan masalah, berhipotesis, merancang percobaan, mengamati, mengklasifikasikan, mengkomunikasikan, memprediksi data, dan menyimpulkan (Eggen dan Kauchak, 2012: 177).

Uji statistik deskriptif dilakukan dalam penelitian ini untuk mengetahui capaian hasil belajar keterampilan proses sains siswa pada materi teori kinetik gas. Menurut Sugiyono (2012: 35), statistik deskriptif adalah statistik yang digunakan untuk menganalisis data dengan cara mendeskripsikan atau menggambarkan data yang telah terkumpul sebagaimana adanya tanpa bermaksud membuat kesimpulan yang berlaku untuk umum atau generalisasi. Menurut Arikunto (2010: 161) analisis hasil belajar keterampilan proses siswa meliputi :

\section{Daya Serap}

Daya serap siswa didefinisikan sebagai kemampuan siswa menyerap materi yang disajikan dalam proses pembelajaran.
Daya serap $=$

$\frac{\text { scores obtained by students }}{\text { Scores maximum }} \times 100 \%$

Untuk mengkategorikan daya serap yang diperoleh siswa dari hasil belajar digunakan kriteria sebagai berikut :

Tabel 1. Kategori Daya Serap Siswa

\begin{tabular}{lc}
\hline Interval $(\boldsymbol{\%})$ & Kategori Daya Serap \\
\hline $\mathbf{8 5} \geq \mathbf{x} \leq \mathbf{1 0 0}$ & Amat baik \\
$\mathbf{7 0} \geq \mathbf{x}<\mathbf{8 5}$ & Baik \\
$\mathbf{5 0} \geq \mathbf{x}<\mathbf{7 0}$ & Cukup baik \\
$\mathbf{0} \geq \mathbf{x}<\mathbf{5 0}$ & Kurang baik \\
\hline
\end{tabular}

Berdasarkan tabel 1 dapat dilihat bahwa daya serap siswa dapat dikelompokkan menjadi 4 kategori sesuai dengan interval skor postes masing-masing siswa. Interval nilai tertinggi yaitu $85 \geq \mathrm{x} \leq 100$ dengan kategori amat baik dan interval nilai terendah yaitu $0 \geq$ $\mathrm{x}<50$ dengan kategori kurang baik. Siswa dapat memiliki daya serap amat baik ketika mampu menerapkan pendekatan inkuiri dengan baik ketika proses pembelajaran.

\section{Efektivitas Pembelajaran}

Efektivitas pembelajaran adalah keberhasilan suatu pembelajaran berdasarkan daya serap rata-rata kelas.

Tabel 2. Kategori Efektivitas Pembelajaran

\begin{tabular}{ll}
\multicolumn{1}{c}{$\begin{array}{c}\text { Daya Serap } \\
\text { Rata-Rata Kelas }\end{array}$} & Kategori \\
\hline $\mathbf{8 5} \geq \mathbf{x} \leq \mathbf{1 0 0}$ & Sangat efektif \\
$\mathbf{7 0} \geq \mathbf{x}<\mathbf{8 5}$ & Efektif \\
$\mathbf{5 0} \geq \mathbf{x}<\mathbf{7 0}$ & Cukup efektif \\
$\mathbf{0} \geq \mathbf{x}<\mathbf{5 0}$ & Kurang efektif \\
\hline
\end{tabular}

Tingkat efektivitas pembelajaran siswa dapat dikategorikan sesuai pada tabel 2 . Pembelajaran dapat dikatakan sangat efektif ketika siswa memiliki daya serap amat baik, sedangkan pembelajaran berlangsung kurang efektif ketika daya serap siswa kurang baik dalam memahami materi yang diajarkan.

Analisis penyelesaian soal-soal hasil tes dimaksudkan apakah siswa lulus atau tidak lulus pada aspek indikator keterampilan proses. Kriteria pengelompokkan siswa menjadi kelompok yang lulus atau tidak lulus pada 
aspek tertentu adalah batas kelulusan dari tiap aspek yang dinyatakan sebagai batas minimum. Batas kelulusan yang digunakan adalah batas lulus ideal dengan menggunakan rumus:

$$
\overline{\mathrm{X}}_{\text {ideal }}=\frac{1}{2} \text { Skor Maksimum }
$$

$$
\begin{aligned}
& \mathrm{SD}_{\text {ideal }}=\frac{1}{3} \overline{\mathrm{X}}_{\text {ideal }} \\
& \overline{\mathrm{X}}_{\text {minimum }}=\overline{\mathrm{X}}_{\text {ideal }}+0,25 \cdot \mathrm{SD}_{\text {ideal }}
\end{aligned}
$$

Siswa dinyatakan tidak lulus jika siswa memperoleh nilai kurang dari $\overline{\mathrm{X}}_{\text {minimum }}$ atau tidak memberikan jawaban dan siswa dianggap lulus jika siswa memperoleh nilai lebih dari atau sama dengan $\overline{\mathrm{X}}_{\text {minimum. }}$. Dalam penelitian ini skor maksimum indikator adalah berbeda. Berdasarkan persamaan 1, 2 dan 3 didapatkan nilai skor maksimum dan batas lulus untuk tiap tahap yang ditunjukkan pada tabel 3 .

Tabel 3.Batas Lulus Kemampuan Pemecahan Masalah

\begin{tabular}{lccc}
\hline $\begin{array}{c}\text { Indikator } \\
\text { Keterampilan } \\
\text { Proses }\end{array}$ & $\begin{array}{c}\text { Nom } \\
\text { or } \\
\text { Soal }\end{array}$ & $\begin{array}{c}\text { Skor } \\
\text { Maks }\end{array}$ & BL \\
\hline Merencanakan & 1 & 5.0 & 2.7 \\
Percobaan & 2 & 10 & 5.4 \\
Mengkomunikasikan & 3 & 5.0 & 2.7 \\
Mengklasifikasikan & 4 & 10 & 5.4 \\
Memprediksi & 5 & 10 & 5.4 \\
Mengamati & 6 & 5.0 & 2.7 \\
Merumuskan & 7 & 5.0 & 2.7 \\
Masalah & 8 & 5.0 & 2.7 \\
Merancang Hipotesis & & & \\
Menyimpulkan & &
\end{tabular}

Keterangan:

Nilai Maks : Nilai Maksimum

Nilai BL : Nilai Batas Lulus

Tabel 3 menunjukkan bahwa batas lulus tiap indikator berada pada skala nilai 2,7 dan 5,4 . Adapun yang indikator soal yang memiliki skor batas lulus 2,7 adalah aspek keterampilan proses pada tingkatan dasar dan skor batas lulus 5,4 merupakan indikator soal sesuai aspek keterampilan proses tingkatan terintegrasi.

\section{Hasil Penelitian dan Pembahasan}

Hasil tes keterampilan proses sains siswa berbasis pendekatan inkuiri diolah dengan menggunakan persamaan 1. Berdasarkan hasil analisis deskriptif didapatkan daya serap siswa terbagi menjadi 4 kategori dan efektivitas pembelajaran.

Tabel 4. Daya Serap Keterampilan Proses Siswa pada Materi Teori Kinetik Gas

\begin{tabular}{cclcc}
\hline No & Interval & Kategori & $\begin{array}{c}\text { Jumlah } \\
\text { Siswa }\end{array}$ & $\begin{array}{c}\text { Jumlah } \\
\text { Siswa } \\
(\%)\end{array}$ \\
\hline 1 & $\begin{array}{c}85- \\
100\end{array}$ & Amat & 14 & 38,89 \\
\hline 2 & $70-84$ & Baik & 13 & 36,11 \\
\hline 3 & $50-69$ & Cukup & 5 & 13,89 \\
& Baik & & 11,11 \\
\hline 4 & $0-49$ & Kurang & 4 & 74,95 \\
\hline \multicolumn{5}{c}{ Baik } \\
\hline \multicolumn{5}{c}{ Kategori } \\
\hline
\end{tabular}

Tabel 4 menunjukkan bahwa daya serap siswa tersebar pada seluruh kategori. Daya serap siswa paling dominan berada pada kategori amat baik yaitu sebanyak 14 siswa dari 36 siswa dengan persentase sebesar 38,89\%, sedangkan daya serap terendah sebesar $11,11 \%$ dengan jumlah siswa 4 orang. Hal ini menunjukkan bahwa siswa yang memiliki kemampuan daya serap kurang baik sangat sedikit. Daya serap siswa tergantung pada tingkat kecerdasan siswa, daya ingat yang tinggi, dan guru yang profesional. Pada kegiatan pembelajaran ini, siswa yang memiliki daya serap kurang baik diketahui kurang mengikuti proses pembelajaran dengan baik. Pada saat melaksanakan percobaan yang bertujuan untuk menemukan dan memahami konsep pada materi teori kinetik gas, siswa kurang fokus dan bersikap mudah menyerah ketika tidak menemukan hasil percobaan yang diharapkan. Selain itu, siswa tidak mampu memahami dengan baik setiap tahapan dalam melaksanakan percobaan hingga memperoleh data, sehingga siswa mudah lupa.

Berdasarkan persentase daya serap ratarata siswa pada tabel 4 maka dapat dinyatakan bahwa kefektivan pembelajaran yang dilakukan siswa berlangsung secara efektif yang ditunjukkan dengan presentase daya serap ratarata siswa sebesar $74,95 \%$. Indikator 
keterampilan proses yang dinilai disesuaikan dengan pendekatan inkuiri yang diterapkan saat proses pembelajaran. Hal ini menjadi sarana latihan bagi siswa agar dapat terampil dalam mengembangkan sikap ilmiah siswa yang berpotensi dalam mencapai keterampilan proses yang baik.

Analisis persentase jumlah siswa kelas XI MIA 3 SMA Negeri 4 Pekanbaru yang lulus untuk setiap indikator keterampilan proses disajikan pada tabel 5.

Tabel 5. Persentase jumlah siswa yang lulus untuk setiap indikator

\begin{tabular}{lcccccccc}
\hline No & $\mathbf{1}$ & $\mathbf{2}$ & $\mathbf{3}$ & $\mathbf{4}$ & $\mathbf{5}$ & $\mathbf{6}$ & $\mathbf{7}$ & $\mathbf{8}$ \\
\hline TK & D & T & D & T & D & T & T & D \\
\hline JSL & 35 & 28 & 25 & 22 & 28 & 27 & 22 & 29 \\
\hline (\%) & 97 & 77 & 69 & 61 & 77 & 75 & 61 & 80 \\
\hline
\end{tabular}

Keterangan :

TK : Tingkatan keterampilan proses

D/T : Dasar/ Terintegrasi

JSL : Jumlah siswa yang lulus

Tabel 5 menunjukkan bahwa jumlah siswa yang lulus pada tiap indikator soal bervariasi. Terdapat 4 soal yang diberikan berdasarkan tingkatan keterampilan proses sains. Jumlah terbesar terdepat pada indikator soal nomor 1 sebanyak 35 siswa dan terkecil pada soal nomor 4 dan nomor 7 sebanyak 22 siswa. Persentase skor sesuai dengan tingkatan keterampilan proses menunjukkan bahwa persentase jumlah siswa yang lulus pada indikator soal dasar lebih besar dibandingkan tingkatan terintegrasi. Persentase tertinggi yang dicapai siswa yaitu pada soal nomor 1 sebesar $97 \%$ dan terendah pada soal nomor 4 dan nomor 7 sebesar $61 \%$.

Hasil belajar keterampilan proses sains siswa dapat dikelompokkan berdasarkan tingkatan dasar dan terintegrasi yang ditunjukkan pada Gambar 2.

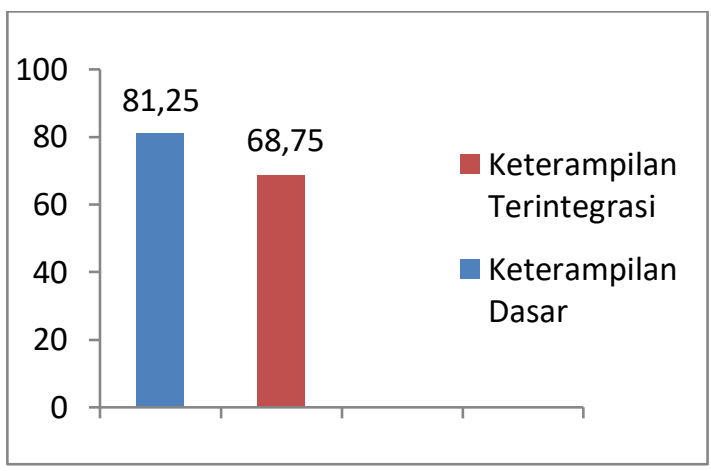

Gambar 2. Persentase Jumlah Kelulusan Siswa untuk Tiap Tingkatan Keterampilan Proses

Gambar 2 menunjukkan bahwa keterampilan proses sains siswa terbagi menjadi dua kategori yaitu keterampilan dasar dan keterampilan terintegrasi. Persentase skor siswa pada keterampilan dasar lebih tinggi dibandingkan keterampilan terintegrasi sebesar 81,25\% dengan perbandingan skor 1,18: 1 . Adapun indikator soal pada aspek keterampilan proses sains siswa tiap tingkatan dapat dijelaskan sebagai berikut:

\section{Keterampilan Dasar}

\section{a. Merencanakan Percobaan}

Indikator ini bertujuan untuk mengetahui kemampuan siswa dalam merencanakan percobaan. Indikator ini akan tercapai apabila siswa mengetahui alat dan bahan apa saja yang dibutuhkan untuk melakukan percobaan sesuai penjelasan yang tercantum pada Lembar Kegiatan Peserta Didik (LKPD). Siswa diberikan sebuah pertanyaan yang merujuk pada indikator merencanakan percobaan, yaitu pertanyaan dengan nomor soal 1 . Berdasarkan hasil analisis yang disajikan pada Gambar 2 menunjukkan bahwa $97.22 \%$ dari jumlah siswa secara keseluruhan lulus dalam merencanakan percobaan. Salah satu pelajaran fisika kelas XI SMA adalah teori kinetik gas yang merupakan materi yang membutuhkan pemikiran yang abstrak. Selama ini pembelajaran dilakukan oleh guru pada teori kinetik gas masih menggunakan ceramah diselingi dengan diskusi.

Pada pembelajaran ini sebenarnya guru dapat mengajak siswa untuk mengamati kejadian untuk menggiring pada pemahaman materi, sehingga pembelajaran bisa berlangsung lebih baik jika menerapkan suatu 
media pembelajaran berupa perangkat percobaan. Perangkat percobaan yang digunakan ini berfungsi sebagai sarana siswa agar lebih mudah memahami konsep pada materi teori kinetik gas ini. Siswa diberi kesempatan untuk menemukan konsep secara mandiri dengan memaksimalkan keterampilan merencanakan percobaan dengan cara menentukan alat percobaan, melakukan pengamatan, dan menentukan langkah kerja untuk memulai percobaan. Roestiyah (2008: 96) juga menyatakan bahwa pada indikator keterampilan proses ini siswa telah berhasil melaksanakan salah satu pokok dari pendekatan inkuiri yaitu siswa memiliki kebebasan untuk belajar secara mandiri ditunjukkan dengan persentase jumlah siswa yang lulus pada indikator merencanakan percobaan ini berada pada kategori amat baik.

\section{b. Mengklasifikasikan}

Indikator ini bertujuan untuk mengetahui kemampuan siswa dalam mengelompokkan data dalam bentuk tabel. Berdasarkan hasil analisis pada Gambar 2 menyatakan bahwa persentase jumlah siswa yang lulus pada indikator mengklasifikasikan yang ditunjukkan pada soal nomor 3 sebesar $69.44 \%$. Terdapat 4 siswa yang mengosongkan jawaban dan 7 siswa yang menjawab tidak tepat. Hal ini disebabkan oleh kurangnya siswa dalam memahami soal sehingga terdapat beberapa siswa yang menjawab tidak tepat tersebut hanya memasangkan atau mengelompokkan data dengan memberi panah, namun jawaban yang diisi siswa tersebut juga tidak sempurna. Pemecahan permasalahan yang dilakukan siswa tidak sesuai dengan yang diperintahkan dalam soal. Kemampuan untuk mengklasifikasikan dibutuhkan kemampuan untuk memilah suatu objek dengan cara mengamati persamaan, perbedaan, dan hubungan dari objek tersebut (Dimyati dan Mudjiono, 2013: 13). Proses mengklasifikasikan, sistem yang digunakan sebaiknya dipilih yang paling sesuai dengan tujuan. Seperti yang dikemukakan oleh Nur (2011) bahwa dalam sains, benda-benda maupun proses-proses dapat diklasifikasikan dengan cara yang berbeda-beda. Hal ini bertujuan agar pengelompokan tersebut mudah dipahami.

\section{c. Mengamati}

Keterampilan mengamati merupakan kemampuan untuk mengumpulkan informasi yang diperoleh dari objek-objek dan fenomena alam dengan menggunakan atau lebih indera yang dimiliki. Dimyati dan Mudjiono (2013: 13) menyatakan bahwa informasi yang diperoleh dari keterampilan mengamati dapat menuntut keingintahuan, mempertanyakan, memikirkan, melakukan interpretasi tentang lingkungan dan mencari lebih lanjut. Kemampuan mengamati merupakan keterampilan paling dasar dalam proses untuk memperoleh ilmu pengetahuan dalam mengembangkan keterampilan proses yang lain. Keterampilan proses pada aspek mengamati menggunakan indikator sebagai berikut:

1) Menggunakan sebanyak mungkin indera yang dimiliki

2) Menggunakan fakta yang relevan

Berdasarkan hasil analisa tes yang telah dilakukan persentase jumlah siswa yang lulus pada keterampilan mengamati sebesar $77,77 \%$. Masih terdapat siswa yang tidak mampu menyelesaikan soal ini dikarenakan kurangnya keseriusan siswa dalam melakukan percobaan sehingga masih mengalami kebingungan ketika mengerjakan soal. Terdapat 4 siswa yang mengosongkan jawaban dan 4 siswa yang menjawab tidak tepat. Sesuai dengan yang dikemukakan oleh Sanjaya (2008: 108) bahwa kesiapan dan keseriusan dalam proses pembelajaran sangat diperlukan karena merupakan salah satu hukum belajar. Inti dari hukum belajar ini adalah bahwa setiap individu akan merespon dengan cepat dari setiap stimulus manakala dalam dirinya belum memiliki kesiapan. Hal senada yang dikemukakan oleh Balim (2009: 18) dalam jurnal internasional bahwa aktivitas dari penyelidikan dengan penemuan dapat digunakan dengan tujuan menggambarkan perhatian dari siswa dan keaktifan mereka untuk berpartisipasi lebih di kelas.

\section{d. Menyimpulkan}

Pada indikator ini siswa diharapkan mampu membuat kesimpulan akhir hubungan suhu, tekanan, dan volume dari data yang diberikan dalam bentuk tabel. Soal yang berhubungan dengan aspek ini terdapat pada 
nomor 8. Berdasarkan hasil analisis pada Gambar 2 menunjukkan bahwa persentase jumlah siswa yang lulus pada indikator ini berada pada urutan terbesar ke-2 yaitu sebesar $80.56 \%$ dari jumlah siswa secara keseluruhan. Namun masih terdapat siswa yang kurang paham dalam mmbaca data di tabel dan memahami hukum yang berkaitan dengan data yang disajikan pada tabel. Kurangnya pemahaman dalam menentukan hubungan suhu, tekanan, dan volume yang disajikan dalam bentuk rumus. Secara umum kesulitan dalam menyelesaikan soal fisika dapat diindikasi dari kemampuan siswa dalam memahami konsep dan kemampuan berpikir memecahkan masalah atau soal. Kurang optimalnya keterampilan menyimpulkan juga disebabkan siswa belum terbiasa untuk menafsirkan dari hasil pengamatan berupa data yang disajikan dalam bentuk tabel kemudian menyusunnya menjadi kesimpulan (Chusni dan Widodo, 2013: 55).

Keterampilan dasar yang ditunjukkan pada soal meliputi keterampilan merencanakan percobaan, mengklasifikasikan, mengamati dan menyimpulkan. Berdasarkan analisis yang telah dideskripsikan pada tiap indikator keterampilan proses tersebut dapat dikelompokkan bahwa persentase jumlah kelulusan siswa pada keterampilan dasar ini sebesar $81,25 \%$ dari jumlah siswa secara keseluruhan. Sebagian besar siswa telah mampu menyelesaikan soal keterampilan proses pada tingkatan dasar dengan baik. Keterampilan dasar merupakan keterampilan proses sederhana yang dimiliki siswa tanpa memerlukan pemikiran tingkat tinggi. Mengingat proses yang telah dilakukan saat pembelajaran juga berpengaruh dalam menyelesaikan soal pada tingkatan keterampilan proses ini. Pada saat proses pembelajaran dengan menerapkan pendekatan inkuiri siswa dilatih untuk terampil dalam mengamati, merencanakan percobaan, melaksanakan percobaan, mengukur, dan menghitung. Keterampilan ini berfungsi dalam melatih daya ingat siswa agar bertahan lama dalam memahami konsep sehingga berpengaruh pada prestasi belajar (Lubis, 2012: 71)

\section{Keterampilan Terintegrasi \\ a. Mengkomunikasikan}

Indikator ini bertujuan untuk mengetahui kemampuan siswa dalam mengkomunikasikan permasalahan dalam bentuk gambar (grafik atau bagan), diskusi dan presentasi. Pada soal nomor 2 yang diberikan dengan memuat indikator ini tercapai apabila siswa mampu menggambarkan data empiris hasil percobaan pada Hukum Boyle dari pengamatan menjadi bentuk grafik. Berdasarkan data yang ditunjukkan pada Gambar 2 sebesar $77.77 \%$ dari jumlah siswa secara keseluruhan dinyatakan lulus pada indikator keterampilan mengkomunikasikan. Siswa yang dinyatakan tidak lulus disebabkan karena adanya siswa yang sama sekali tidak menulis jawaban dan adanya siswa yang menjawab tidak tepat. Hal ini terjadi karena ketidakmampuan siswa dalam merepresentasikan. Siska (2013: 74) menyatakan bahwa tidak tercapainya indikator keterampilan mengkomunikasikan dapat disebabkan oleh tidak terbiasanya siswa dalam menyajikan data yang diperoleh dari hasil percobaan ke dalam bentuk grafik ataupun mengubah bentuk penyajian data karena siswa lebih sering diberikan lembar kerja yang dilengkapi dengan tabel pengamatan. Guru juga jarang melatih siswa untuk terampil dalam berkomunikasi melalui gambar (grafik atau bagan). Hasil analisa ini sesuai dengan hasil penelitian yang dilakukan oleh Liandari, et al (2017: 40) bahwa keterampilan berkomunikasi siswa melalui gambar (grafik atau bagan) hanya mencapai $40 \%$ disebabkan oleh kurang terlatihnya siswa dalam mengkomunikasikan data hasil percobaan dengan mengubah bentuk penyajian data. Proses pembelajaran dengan menerapkan pendekatan inkuiri memerlukan waktu yang tidak sedikit, sehingga kurang maksimal dalam mengulas hasil percobaan yang telah dilakukan dan memberikan latihanlatihan soal kepada siswa (Roestiyah, 2008: 96). Pada pelaksanaan pembelajaran materi Hukum Boyle memiliki beberapa keunggulan dalam penyampaiannya dibandingkan materi lainnya dikarenakan merupakan materi pertama yang diajarkan dengan langkah kerja praktikum yang paling berbeda dari lainnya. Percobaan Hukum Boyle dilaksanakan pertama, sehingga siswa lebih mudah mengingatnya dikarenakan belum tercampur dengan materi teori kinetik gas yang lainnya. Pelaksanaan praktikum untuk 
LKPD 1-4 menggunakan alat yang sama, namun langkah kerja praktikum Hukum Boyle (LKPD 1) memiliki perbedaan yang menonjol dari yang lainnya, yaitu tidak menggunakan es batu sebagai bahan percobaan yang menandakan bahwa suhu tetap. Poin ini membuat siswa menjadi lebih mudah mengingat bahwa pada Hukum Boyle, variabel yang tidak berubah adalah suhu. Sesuai penjelasan tersebut seharusnya menyelesaikan soal yang memuat keterampilan mengkomunikasikan dari data tabel menjadi bentuk grafik lebih mudah diselesaikan dengan melihat variabel yang berubah dan tidak berubah dalam soal yang ditunjukkan.

\section{b. Memprediksi Data}

Keterampilan memprediksi dapat diartikan sebagai membuat ramalan atau perkiraan tentang hal atau kejadian yang akan terjadi pada waktu mendatang, berdasarkan hubungan antara fakta, konsep dan prinsip dalam ilmu pengetahuan. Indikator ini akan tercapai jika siswa mampu memahami hubungan tekanan $(\mathrm{P})$, suhu $(\mathrm{T})$, dan volume (V) pada beberapa data yang ditunjukkan pada tabel dalam soal nomor 4 yang diberikan, sehingga siswa dapat melanjutkan kemungkinan data selanjutnya yang dihasilkan pada percobaan. Berdasarkan data yang ditunjukkan pada Gambar 1 bahwa persentase jumlah siswa yang lulus pada indikator ini termasuk pencapaian terendah dari 8 indikator yang disajikan dalam bentuk soal yaitu sebesar $61.11 \%$. Kesalahan yang masih terjadi ini disebabkan oleh kurangnya kemampuan siswa dalam memahami hubungan tekanan, suhu, dan volume dari data yang telah diberikan, sehingga siswa tidak dapat menyelesaikan soal yang diberikan dengan baik. Hasil skor postest menunjukkan bahwa terdapat 6 siswa yang mengosongkan jawaban dan 8 siswa yang menjawab tidak tepat. Salah satu cara untuk menumbuhkan kemampuan memprediksi yaitu dengan berlatih dalam menentukan pola dan keteraturan dari data hasil percobaan (Siska, 2013: 74). Sebagian kecil siswa tidak mampu dalam membuat strategi sehingga salah dalam menemukan rumus yang harus digunakan dalam menyelesaikan soal. Pada tabel data hasil percobaan yang disajikan menunjukkan bahwa data tersebut memuat hukum Boyle-Gay
Lussac. Pada data tersebut ditunjukkan bahwa nilai suhu, tekanan dan volume selalu berubah. Namun, ada beberapa siswa yang memprediksi tidak sesuai dengan konsep hukum Boyle-Gay Lussac, sehingga untuk memantapkan pemahaman konsep siswa maka data haruslah disajikan dengan cantik dan menarik sehingga kemampuan untuk memprediksi dan mengkomunikasikan akan lebih terarah. Selain itu siswa harus banyak berlatih dan belajar agar mampu mengembangkan kreativitas dalam pemecahan masalah. Perlu adanya perbaikan dengan membimbing siswa dalam merumuskan prediksi, karena indikator tersebut merupakan indikator keterampilan proses yang menuntut siswa untuk berpikir tingkat tinggi (Juhji, 2016: 67).

\section{c. Merumuskan Masalah}

Pada aspek merumuskan masalah ini siswa membuat suatu pertanyaan terhadap studi kasus yang diberikan pada soal nomor 6. Berdasarkan hasil analisis pada Gambar 2 sebesar $75 \%$ dari jumlah siswa keseluruhan dinyatakan lulus pada indikator ini. Siswa yang belum mencapai batas kelulusan pada indikator keterampilan merumuskan masalah disebabkan oleh kurangnya memahami studi kasus yang diberikan sehingga hasilnya tidak sesuai dengan yang diharapkan. Kurangnya keseriusan dalam memahami kembali LKPD yang telah dikerjakan pada pertemuan sebelumnya juga mempengaruhi hasil belajar keterampilan proses yang diukur dari skor hasil tes yang diberikan. Selain itu, kurang mampunya siswa dalam mengidentifikasi masalah yang diberikan dalam bentuk gambar sehingga siswa sulit menemukan rumusan masalah yang sesuai dengan ilustrasi yang diberikan dalam soal. Keterampilan merumuskan masalah ini dilatih melalui Lembar Kerja Peserta Didik (LKPD) berupa memberikan suatu ilustrasi berdasarkan peristiwa dalam kehidupan sehari-hari, kemudian dari hasil reflective observation siswa akan menemukan masalah yang diungkapkan dalam bentuk rumusan masalah (Kastawaningtyas, 2017: 46).

\section{d. Menyusun Hipotesis}

Kemampuan menyusun hipotesis adalah salah satu keterampilan yang sangat mendasar 
dalam kerja ilmiah. Hipotesis adalah suatu perkiraan yang bertujuan untuk menerangkan suatu kejadian atau pengamatan tertentu. Pada keterampilan menyusun hipotesis ini siswa diharapkan mampu membuat dugaan sementara sesuai dengan rumusan masalah yang diajukan. Dugaan sementara yang diajukan harus logis dan dapat diuji dalam suatu percobaan.

Berdasarkan Gambar 2 menunjukkan bahwa persentase jumlah siswa yang lulus pada indikator ini sebesar $61.11 \%$. Siswa yang belum mencapai batas kelulusan pada indikator menyusun hipotesis yang ditunjukkan pada soal nomor 7 disebabkan siswa tersebut tidak memahami rumusan masalah yang dibuat sehingga sulit untuk menemukan hipotesis. Kurangnya kemampuan siswa dalam menyusun hipotesis menunjukkan bahwa siswa belum mampu melaksanakan proses pembelajaran dengan pendekatan inkuiri secara maksimal (Roestiyah, 2008: 96). Keterampilan dalam menyusun hipotesis ini juga dilatih dalam Lembar Kerja Peserta Didik (LKPD) melalui kegiatan eksperimen yang dilakukan pada tahap pemahaman konsep yang masih abstrak. setelah siswa mampu merumuskan masalah maka siswa diberi arahan untuk dapat menemukan dugaan sementara dengan melibatkan dua variabel yang saling berhubungan. Belajar melibatkan banyak melibatkan logika atau gagasan daripada memahami masalah atau situasi. Hal ini merupakan sistematika dalam perencanaan untuk memecahkan suatu masalah (Kastawaningtyas, 2017: 50).

Keterampilan terintegrasi merupakan keterampilan proses hasil dari pengembangan kemampuan siswa pada keterampilan dasar. Berdasarkan Gambar 2 dapat dilihat bahwa persentase jumlah kelulusan siswa pada keterampilan terintegrasi sebesar 68,75\%. Data tersebut menunjukkan bahwa persentase jumlah kelulusan siswa pada keterampilan terintegrasi lebih rendah dibandingkan keterampilan dasar. Secara umum kesalahan individu yang sama terdapat pada indikator merumuskan masalah dan menyusun hipotesis. Pada keterampilan terintegrasi ini sesuai dengan penerapan inkuiri harus sering dilaksanakan latihan agar keterampilan proses yang dimiliki siswa lebih terasah sehingga hasil belajar keterampilan proses pada tingkatan ini menjadi lebih baik.

\section{Kesimpulan dan Rekomendasi}

Kesimpulan dari penelitian yang telah dilakukan yaitu: (1) Pembelajaran berbasis pendekatan inkuiri dapat melatih sikap ilmiah siswa sehingga akan berpengaruh pada keterampilan proses sains siswa. Hal ini dapat dilihat dari keaktifan siswa meningkat selama proses pembelajaran yang dilakukan. Keaktifan ini muncul karena adanya rasa ingin tahu yang tinggi sehingga siswa antusias dalam melakukan percobaan untuk menemukan konsep dari materi teori kinetik gas secara mandiri; (2) Keterampilan proses sains yang dimiliki siswa akan mempengaruhi keterampilan kognitif siswa sehingga siswa dapat memperoleh pemahaman konsep dan hasil belajar yang baik; (3) Daya serap siswa secara umum berada pada kategori baik sehingga proses pembelajaran yang dilakukan berlangsung efektif; (4) Keterampilan proses sains siswa pada tingkatan terintegrasi cukup baik sedangkan pada tingkatan dasar sudah baik; (5) Pembelajaran berbasis pendekatan inkuiri sesuai untuk diterapkan yang bertujuan untuk meningkatkan hasil belajar keterampilan proses sains siswa serta pilihan yang tepat bagi guru dalam menumbuhkan keaktifan dan kreativitas siswa selama proses pembelajaran sehingga pembelajaran tidak berlangsung monoton.

Rekomendasi yang diajukan dari penelitian ini adalah: (1) Guru harus mampu membuat kesiapan siswa untuk melaksanakan percobaan agar data yang diperoleh sesuai dengan tujuan yang ingin dicapai; (2) Penelitian ini bisa dikembangkan dengan menerapkan quasi experiment design agar hasil yang diperoleh lebih maksimal dalam melihat pengaruh pendekatan inkuiri terhadap hasil belajar keterampilan proses sains siswa.

\section{Daftar Pustaka}

Alfiah. (2015). Kemampuan Siswa dalam Menyelesaikan Soal-Soal Uraian Terstruktur Pokok Bahasan Teori Kinetik Gas. Jurnal EduSains, 3(2), 161175.

Arikunto, S. (2010). Prosedur Penelitian Suatu Pendekatan Praktik. Jakarta: Rineka Cipta.

Aydin, A. (2013). Representation of Science Process Skills in the Chemistry Curricula 
for Grades 10, 11, and 12. International Journal Education and Practice, 1(15), 51-63.

Balim, A.G. (2009). The Effects of Discovery Learning on Students Success and Inquiry Learning Skills. Journal of Education Research, 2(1), 1-20.

Chusni, M.M. dan Widodo. (2013). Pengembangan LKS Sains Berbasis Kerja Laboratorium untuk Meningkatkan Keterampilan Proses dan Hasil Belajar Siswa. Prosiding Seminar Nasional FMIPA UKSW Salatiga, 4(1), 2087-0992.

Dimyati dan Mudjiono. (2013). Belajar dan Pembelajaran. Rineka Cipta: Jakarta.

Eggen, P. dan D. Kauchak. (2012). Strategi dan Model Pembelajaran. Jakarta: PT Indeks.

Funk, J.H., Fiel, R. L., Okey, J. R., Jaus, H. H., dan Sprague, C. S. (1985). Learning Science Process Skills (2nd ed.) Dubuque, Iowa: Kendall Hunt Publishing Company.

Jeon, S., \& Park, J.-H. (2014). Analysis of Relationships of Scientific Communication Skills, Science Process Skills, Logical Thinking. Journal of the Korean Association for Science Education, 34(7), 647-655.

Juhji. (2016). Peningkatan Keterampilan Proses Sains Siswa Melalui Pendekatan Inkuiri Terbimbing. Jurnal Penelitian dan Pembelajaran IPA, 2(1), 58-70.

Kastawaningtyas, A. dan Martini. (2017). Peningkatan Keterampilan Proses Sains Siswa Melalui Model Experientatial Learning pada Materi Pencemaran Lingkungan. Jurnal Penelitian Pendidikan IPA, 2(2), 45-52.

Lubis, M.A., M.B. Harahap, dan S.R. Manurung. (2017). Analisis Model Pembelajaran Scientific Inquiry dan Kemampuan Berpikir Logis Terhadap Keterampilan Proses Sains Siswa SMA. Jurnal Pendidikan Fisika, 6(2), 70-75.

Nugroho, S., Suparmi, dan Sarwanto. (2012). Pembelajaran IPA dengan Metode Inkuiri Terbimbing Menggunakan Laboratorium Riil dan Virtuil Ditinjau dari Kemampuan Memori dan Gaya Belajar Siswa. Inkuiri: Jurnal Pendidikan IPA, 1(3), 235-244.
Nur, M. (2011). Modul Keterampilanketerampilan Proses Sains. Pusat Sains dan Matematika Sekolah: Universitas Negeri Surabaya.

Oloyede, O.I. (2012). The Relationship between Acquisition of Science Process Skills, Formal Reasoning Ability and Chemistry Achievement. International Journal of Advanced and Applied Sciences, 8(1), 1-4.

Osman, K. dan R. Vebrianto. (2013). Fostering Science Process Skills and Improving Achievement Through The Use of Multiple Media. Journal of Baltic Science Education, 12(2), 191-204.

Ozdemir, G. dan A. Dikici. (2017). Relationships between Scientific Process Skills and Scientific Creativity: Mediating Role of Nature of Science Knowledge. Journal of Education in Science, Environment and Health, 3(1), 52-68.

Pranoto, A.M.S., Sajidan, dan B.A. Prayitno. (2018). Pengembangan Modul Berbasis Inquiry Lab pada Materi Sistem Gerak untuk Meningkatkan Hasil Belajar Siswa Kelas XI SMAN 1 Mejayan. INKUIRI: Jurnal Pendidikan IPA, 7(2), 232-242.

Roestiyah, N.K. (2008). Strategi Belajar Mengajar. Rineka Cipta. Jakarta.

Rahmanto, K.F., M. Masykuri, dan W. Sunarno. (2015). Pengembangan Modul IPA Terpadu Berbasis Inkuiri Terbimbing dengan Tema Keju untuk Meningkatkan Keterampilan Proses Sains dan Hasil Belajar Siswa SMP Kelas VII. Inkuiri: Jurnal Pendidikan IPA, 4(4), 109-120.

Santoso, T. dan L. Yuanita. (2016). Pengembangan Bertanya Kritis Berbasis Inkuiri (BKBI) untuk Pembelajaran Kimia. Jurnal Pendidikan Sains, 4(1), 916.

Setianingsih, E., W. Sunarno, dan Sukarmin. (2018). Pengembangan Modul Pembelajaran Dinamika Gerak Berbasis Inkuiri Terbimbing untuk Siswa Kelas X SMA/MA. Inkuiri: Jurnal Pendidikan IPA, 7(2), 220-231.

Sugiyono. (2012, 2013). Metode Penelitian Kuantitatif Kualitatif dan $R \& D$. Alfabeta: Bandung. 
Susilo, A., W. Sunarno, dan Sukarmin. (2018). Pembelajaran Fisika Menggunakan Metode Inkuiri Terbimbing dan Inkuiri Bebas Termodifikasi Berdasarkan Kompendium Al-Qur'an Ditinjau dari Kedisiplinan Belajar dan Sikap Ilmiah. Inkuiri: Jurnal Pendidikan IPA, 7(2), 160-167.
Trianto. (2010). Model Pembelajaran Terpadu. Jakarta: Bumi Aksara

Zeidan, A.H. dan M.R. Jayosi. (2015). Science Process Skills and Attitudes toward Science among Palestinian Secondary School Students. World Journal of Education, 5(1), 13-24. 